\title{
Pamiętnikarstwo wojskowe czasów Jana III Sobieskiego (1674-1696). Próba bilansu
}

Marek Wagner 
ИAPIS Seria VII 2001

\section{Marek Wagner}

\section{Pamiętnikarstwo wojskowe czasów Jana III Sobieskiego (1674-1696). Próba bilansu}

\section{Pamiętniki i diariusze}

$\mathrm{P}$ amiętnikarstwo, zdaniem współczesnych badaczy, funkcjonuje obecnie jako gałąź piśmiennictwa, obejmująca szeroką gamę jej odmian gatunkowych — nie tylko pamiętniki, autobiografie i dzienniki, ale także raptularze, relacje podróżnicze i poselskie, wspomnienia i wyznania ${ }^{1}$. Według Andrzeja Cieńskiego

budowa morfologiczna wyrazu „pamiętnikarstwo” może jednak sugerować, że określa on nie tylko i nie tyle gotowe wytwory sztuki pisarskiej, lecz również sam proces „produkowania” czy też „wytwarzania” tekstów pamiętnikarskich ${ }^{2}$.

Zdaniem tegoż badacza, nie jest obecnie możliwe przedstawienie dokładnej definicji „pamiętnikarstwa" oraz oddzielenia jej od innych gatunków literackich i piśmienniczych, na przykład biografii lub listów, a tym bardziej analizy wzajemnych odniesień między gatunkami (pamiętniki — autobiografie - diariusze). Potwierdza to wieloletnia i niezwykle płodna dyskusja badaczy nad określeniem terminów „pamiętnik” czy też „diariusz”, w której zabierali głos najwybitniejsi polscy historycy, jak Władysław Czapliński, Alojzy Sajkowski, Adam Przyboś, Marian Kaczmarek, Janina Rytel i Andrzej Cieński ${ }^{3}$. Pomimo różnych propozycji badawczych dyskusja ta trwa nadal, i będzie

1 Zob. A. Cieński, Pamiętniki i autobiografie światowe, Wrocław 1992, s. 15-33, 40-50; idem, Pamiętnikarstwo polskie XVIII wieku, Wrocław 1981, passim (w obu monografiach bogata literatura polska i zagraniczna).

${ }^{2}$ Idem, Pamiętniki i autobiografie..., op. cit., s. 15.

${ }^{3}$ Podstawowa literatura przedmiotu podana w pracach A. Cieńskiego, zob. przyp. 1; zob. takżc: A. Przyboś, Pamiętnikarstwo polskie w czasach Jana III, „Studia Historyczne”, t. 28, 1985, z. 2 (109), s. 201-221; A. Sajkowski, Nad staropolskimi pamiętnikami, Poznań 1964, passim; B. Królikowski, Wśród Sarmatów. Radziwiłlowie i pamiętnikarze, Lublin 2000, s. 75-158; opinie znakomitych badaczy - W. Czapliński, Pamiętnik jako źródto dla historyka nowożytnego,

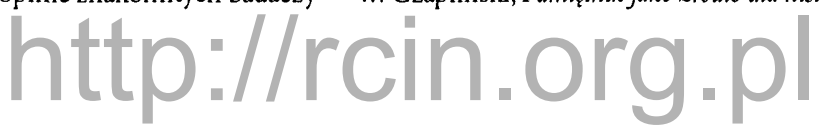


zapewne jeszcze długo trwała, przy okazji wydawania drukiem kolejnych pamiętników i diariuszy. Zatem zgadzamy się z opinią Andrzeja Cieńskiego, iż w chwili obecnej pozostaniemy jedynie przy dość ogólnej definicji pamiętnikarstwa, mając świadomość funkcjonowania w piśmiennictwie wielu jego gatunków oraz podgatunków ${ }^{4}$. Wymaga natomiast określenia drugi człon tytułu niniejszej wypowiedzi. Termin „pamiętnikarstwo wojskowe” zdefiniujemy jako efekty działalności pisarskiej wojskowych (żołnierzy, oficerów oraz dowódców), ale również obserwatorów, oglądających działania wojenne, z bliższej lub dalszej perspektywy, z racji pełnienia obowiązków lub po prostu ze zwykłej ludzkiej ciekawości. Zdajemy sobie jednak sprawę, że definicja ta, bardzo ogólna, wymaga jeszcze dalszych badań, lecz dla potrzeb naszego artykułu wydaje się wystarczająca, bowiem będzie obejmować w miarę wszystkie rozpoznane gatunki i podgatunki krajowego pamiętnikarstwa.

Jak już wspomnieliśmy, polscy historycy nie ustalili wprawdzie dotąd definicji „pamiętnikarstwa”, lecz w wyniku wieloletniej i ożywionej dyskusji opracowali katalog podstawowych, dla czasów nowożytnych, jego gatunków (form pamiętnikarskich). Władysław Czapliński podzielił je na dwa zasadnicze: diariusze (dzienniki) oraz pamiętniki (wspomnienia), podkreślając również bogactwo podgatunków polskiego piśmiennictwa. Do pierwszego gatunku włączył zatem właściwe diariusze (podróży, wypraw wojennych, sejmów, elekcji i poselstw), lecz także raptularze oraz dzienniki listowe. Z kolei do drugiego gatunku zaliczył osobiste pamiętniki, opisy życia autorów, wypadków publicznych i typowe autobiografie ${ }^{5}$. Natomiast Andrzej Cieński, zgadzając się praktycznie na zaproponowany podzial, wydzielit jednak autobiografie jako odrębny gatunek, poświęcając zresztą jego analizie wiele miejsca w swych monografiach ${ }^{6}$.

Wydaje się zatem, że zaproponowany przez znakomitych badaczy podział na dwa gatunki odpowiada nadto potrzebom naszego tekstu. Problem zaczyna się jednak przy bliższej analizie podgatunków „pamiętnikarstwa wojskowego”, bowiem od pewnego czasu pojawiły się w literaturze przedmiotu nowe, dodatkowe terminy — „pamiętnik żołnierski” (w odniesieniu do zapisków Hieronima Chrystiana Holstena, Jakuba Łosia i Jana Władysława Poczobuta Odlanickiego) ${ }^{7}$ oraz „diariusz służby wojennej” (Mikołaja Złotnickiego oraz Poczobuta Odlanickiego) ${ }^{8}$, nie wspominając już o formach pośrednich (Stanisława Zygmunta Druszkiewicza oraz Krzysztofa Zawiszy). Nadto pojawił się termin „diariusze żołnierskie” jako tłumaczenie nowożytnych, angielskich diaries, nie znajdując jednak zastosowania w krajowej literaturze ${ }^{9}$. Nie rozstrzygając w tym miejscu problemu (zasługuje on bowiem na dalszą i pogłębioną analizę), będziemy stosować podwójną terminologię, konsekwentnie odpowiadającą podziałowi Władysława Czaplińskiego na dwa gatunki polskiego pamiętnikarstwa. Oczywiście mowa tutaj o pamiętnikach i diariuszach niejako

„Pamiętnikarstwo Polskie”, t. 2, 1972, nr 2, s. 2-7; A. Przyboś, Rola pamiętnikóu staropolskich u' mojej pracy naukowej, ibidem, nr 3, s. 57-61.

${ }^{4}$ Zob. A. Cicński, op. cit., s. 17-18.

5 Zob. W. Czapliński, op. cit., s. 2-7.

${ }^{6}$ Zob. A. Cieński, op. cit., s. 41-50.

7 Zob. H. Ch. Holsten, Przygody wojenne 1655-1666, opr. J. Leszczyński, T. Wasilcwski, J. Przcwłocki, Warszawa 1980 , s. 5-6.

${ }^{8}$ Zob. M. Wagner, Mikołaj Zlotnicki i jego diariusz wojenny (1648-1696), „Biulctyn Bibliotcki Jagicllońskicj”, t. 45, 1995, nr 1/2, s. 101-102.

9 Zob. A. Cieński, op. cit., s. 131-133.

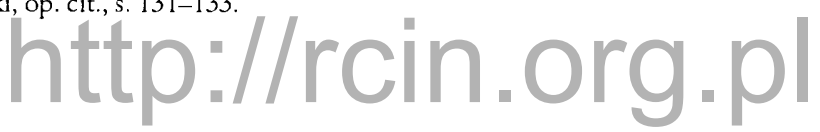


autorskich, wykluczamy bowiem $z$ analizy sprawozdania $z$ kampanii wojennych opracowane i prezentowane przez hetmanów w formie sprawozdań sejmowych ${ }^{10}$, ale także bogaty dorobek okolicznościowej poezji o treści politycznej i wojennej (Stanisława Makowieckiego, Rafała Leszczyńskiego, Wacława Potockiego, Zbigniewa i Jana Andrzeja Morsztynów, Stanisława Herakliusza Lubomirskiego, Stanisława Samuela Szemiota i Stefana Jana Ślizienia) ${ }^{11}$. Ze zrozumiałych powodów nie możemy jednak zrezygnować z opisu oraz analizy tak zwanych pamiętników listowych (Kazimierza Sarneckiego, Dominika Stanisława Wilczka, Tomasza Perkowicza, jak również rodziny Dobińskich) ${ }^{12}$. Rzecz charakterystyczna, te ostatnie pisane jedynie przez „obserwatorów", nie przez wojskowych, przynosiły cotygodniowe relacje (diariusze), opisujące ówczesne wypadki publiczne, w tym także przebieg kampanii wojennych.

Zacznijmy naszą prezentację od pamiętników wojskowych — jeszcze lat trzydziestych i czterdziestych XVII wieku sięgają zapisy w pamiętnikach Aleksandra Dionizego Skorobohatego, towarzysza jazdy ${ }^{13}$, Jana Wladysława Poczobuta-Odlanickiego, towarzysza jazdy ${ }^{14}$, Piotra Opalińskiego, rotmistrza ${ }^{15}$, Stanisława Zygmunta Druszkiewicza, pułkownika oraz regimentarza ${ }^{16}$, Jana Andrzeja Sierakowskiego, rotmistrza ${ }^{17}$, któregoś z Wodzickich, towarzysza jazdy ${ }^{18}$, zapewne Jana Polanowskiego, także towarzysza jazdy ${ }^{19}$, Mikołaja Złotnickiego, pułkownika ${ }^{20}$, Mikołaja Jemiołowskiego, towarzysza jazdy ${ }^{21}$ oraz Floriana Drobysz Tuszyńskiego, także towarzysza ${ }^{22}$. Od lat pięćdziesiątych i sześćdziesiątych pojawiają się nazwiska dobrze znanych pamiętnikarzy — Jana Chryzostoma Paska, towarzysza jazdy ${ }^{23}$, raczej obserwatora niż wojskowego - Jana Antoniego Chrapowickiego $^{24}$ oraz Krzysztofa Zawiszy, rotmistrza jazdy ${ }^{25}$. Z kolei od lat osiemdziesiatych

10 Por. między innymi wykaz sprawozdań z działań wojennych hetmana wielkiego koronnego Stanisława Jabłonowskiego za lata 1683-1699. Zob. M. Wagner, Stanistaw Jabtonowski (1634-1702). Polityk i dowódca, Siedlce 1997, tabcla 8.

1 Zob. odpowiednie hasła w: Bibliografia literatury polskiej „Nowy Korbut”, t. 1-3: Piśmiennictwo staropolskie, opr. R. Pollak z zcsp., Warszawa 1963-1965.

12 Zob. K. Sarnccki, Pamiętniki z czasów Jana Sobieskiego. Diariusz i relacje z lat 1691-1696, wyd. J. Woliński, Wrocław 1958; dalsze relacje: Archiwum Główne Akt Dawnych w Warszawic (dalcj: AGAD), Archiwum Radziwiłlowskic (dalcj: AR), dz. V, t. 342, nr 13939 oraz Bibliotcka Narodowa w Warszawic (dalcj: BN), rps 3349; D. S. Wilczck, listy do Jana III z lat 1693-1695, Biblioteka Zakładu Narodowego im. Ossolińskich we Wrocławiu (dalcj: BOss.), rps 452; silva rerum Wilczków, rps BOss. 2029; korespondencja T. Perkowicza, AGAD, Archiwum Zamoyskich, nr 1380; „Kodeks Dobińskich”, rpsy BN III. 6639, 6640, 6643, 6648-6649, 6651-6652.

13 Zob. A. D. Skorobohaty, Diariusz, opr. T. Wasilewski, Warszawa 2000.

14 Zob. J. W. Poczobut-Odlanicki, Pamiętnik [1640-1684], opr. A. Rachuba, Warszawa 1987.

15 Zob. Księga rodzinna Opalińskich [diariusz Piotra Opalińskiego z lat 1631-1689], Biblioteka Uniwersytecka w Warszawic (dalej: BUW), rps 47.

16 Zob. S. Z. Druszkiewicz, Pamiętniki 1648-1697, opr. M. Wagner, Siedlce 2001.

17 Zob. J. A. Sierakowski, diariusz z lat 1648-1698, Bibliotcka Czartoryskich w Krakowie (dalej: BCzart.), rps 862.

${ }_{18}$ Zob. Wojny i transakcyje różne [1648-1697], rps BOss. 12806.

${ }_{19}$ Zob. Compendium czyli zebranie krótkie wojen od kozackich poczynających się, rpsy BCzart. 181, BOss. 12806.

${ }^{20}$ Zob. M. Wagner, Mikolaj Ztotnicki..., op. cit., s. 116-132.

${ }_{21}$ Zob. M. Jcmiolowski, Pamiętnik dzieje Polski zawierajacy (1648-1679), opr. J. Dziçgiclewski, Warszawa 2000.

${ }_{22}$ Zob. Dwa pamiętniki z XVII wieku - Jana Cedrowskiego i Jana Floriana Drobysz Tuszyńskiego, opr. A. Przyboś, Wrocław 1954.

${ }^{23}$ Zob. J. Pasck, Pamiętniki, opr. W. Czapliński, Wrocław 1979 (BN I 62).

24 Zob. J. A. Chrapowicki, Diariusz, cz. 1: 1656-1664, opr. T. Wasilcwski, Warszawa 1978; cz. 2: 1665-1669, opr. i wyd. A. Rachuba, T. Wasilewski, Warszawa 1988.

${ }_{25}$ Zob. K. Zawisza, Pamiętniki (1666-1721), wyd. J. Bartoszewicz, Warszawa 1862.

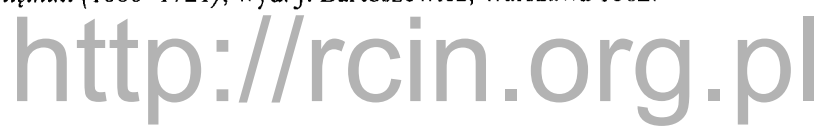


i dziewięćdziesiątych — Francuzów: Franciszka Daleraca ${ }^{26}$, Filipa de Mason Duponta ${ }^{27}$ i Gaspara de Tende ${ }^{28}$, inżynierów wojskowych, Stefana Kostrowskiego, towarzysza jazdy ${ }^{29}$, „zamojskiego” obserwatora, Zachariasza Arakiełowicza ${ }^{30}$, Karola Stanisława Radziwiłła ${ }^{31}$ iJana Stanisława Jabłonowskiego $^{32}$, tytularnych szefów jednostek wojskowych, oraz dwóch towarzyszy jazdy: Franciszka Lach Szyrmy $^{33}$ i Waleriana Puchalskiego ${ }^{34}$.

Liczniejsza jest grupa autorów diariuszy wojskowych, chociaż należy tutaj podkreślić istnienie wielu zapisków anonimowych, niezidentyfikowanych, stąd te $\dot{z}$, jedynie w celu uporządkowania materiału, zaprezentujemy go w układzie chronologicznym. Jeszcze przedkrólewskich kampanii Jana Sobieskiego z lat 1671-1672 dotyczą diariusze autorstwa Pawła Pinocciego ${ }^{35}$. Autorem opisu oblężenia Lwowa w 1672 roku był Józef Bartłomiej Zimorowic ${ }^{36}$. Zachowało się nadto kilka anonimowych diariuszy, opisujących wyprawę hetmana wielkiego koronnego na czambuły tatarskie jesienią 1672 roku, czasami mylnie przypisywanych osobie Jana Sobieskiego ${ }^{37}$. Zwycięska bitwa pod Chocimiem w roku 1673 przyniosła niezliczoną liczbę anonimowych relacji i diariuszy, my zajmiemy się tylko tymi, których autorów znamy, tj. Pawła i Hieronima Pinoccich oraz Adama Przyborowskiego ${ }^{38}$. Oblężenie Trembowli w roku 1675 opisano jedynie w dwóch anonimowych diariuszach, powstałych zapewne w kręgu Jana III $^{39}$. Także zwycięskiej batalii pod Lwowem $\mathrm{w}$ tymże roku poświęcono trzy diariusze, w tym jeden autorski, znanego już nam Józefa Zimorowica $^{40}$. Z kampanii żórawińskiej 1676 roku posiadamy diariusze hetmańskie - Dymitra Wiśniowieckiego, koronnego ${ }^{41}$, i Michała Kazimierza Paca, litewskiego ${ }^{42}$, zaś prócz kilku anoni-

${ }^{26}$ Zob. F. Dalerac, Pamiętniki kawalera de Beaujeu, t1. A. Kraushar, Kraków 1883.

27 Zob. F. Dupont, Pamiętniki do historii życia i czynów Jana III Sobieskiego, wyd. J. Janicki, Warszawa 1885.

${ }_{28}$ Zob. G. de Tende (de Hauteville), Relacja historyczna o Polsce, w: Cudzoziemcy o Polsce. Relacje i opinie, wyb. i opr. J. Gintel, t. 1: wieki X-XVII, Kraków 1971, s. 310-334.

${ }^{29}$ Zob. Przypadki różne ciekawe, nadarzone za Jana Sobieskiego, wyjęte z rękopismu P. Stefana Kostrowskiego towarzysza ussarskiego, „Tygodnik Petersburski”, R. 13, 1843, cz. 25, nr 1-50.

30 Zob. Zachariasza Arakielowicza connotacyja, co się dziato od roku 1689 po części w Zamościu i w catej Rzeczypospolitej, rps BUW 88.

${ }^{31}$ Zob. K. S. Radziwill, Diariusz [1689-1718], AGAD, AR, dz. VI, nr II-79.

${ }^{32}$ Zob. J. S. Jabłonowski, Dziennik, wyd. W. Chomętowski, Warszawa 1865; idem, Pamiętnik, wyd. A. Biclowski, Lwów 1862; idem, Ulamki dziennika, „Kronika Rodzinna” 1888-1889.

${ }_{33}$ Zob. Pamiętnik Stanisława i Franciszka Lachów Szyrmów, 1665-1668, 1690-1732, Bibliotcka im. Zielińskich Towarzystwa Naukowego Płockiego, rps 102.

${ }^{34}$ Zob. Notatki Waleriana Puchalskiego (od 1690 do 1718), wyd. J. I. Kraszewski, „Athenaeum”, t. 6, Wilno 1846, s. $174-181$.

35 Zob. P. Pinocci, relacje z lat 1671-1672, Archiwum Państwowe w Krakowie, rps 372 i 373.

36 Zob. J. Zimorowic, Historia miasta Lwowa..., tł. M. Piwocki, Lwów 1835.

37 Zob. K. Zawadzki, Gazety ulotne polskie i Polski dotyczace XVI-XVIII wieku. Bibliografia, t. 2: 1662-1728, Wrocław 1984, nr 900-903.

38 Zob. ibidem, nr 906-916.

39 Zob. ibidem, nr 930, 935.

40 Zob. ibidem, nr 932, 937.

${ }^{41}$ Zob. D. Wiśniowiecki, Relacyja wszystkich transakcyj od sejmu coronationis Króla J. M. do zejścia z pola Króla J. M. i wojsk JKM, 1676, rps BN, BOZ 1222.

${ }^{42}$ Zob. M. Pac, Diariusz, 9 VIII-20X 1676, rps BCzart. 421; wyd. J. Woliński, „Przegląd Historyczno-Wojskowy”, t. 2,1930 , z. 1 .

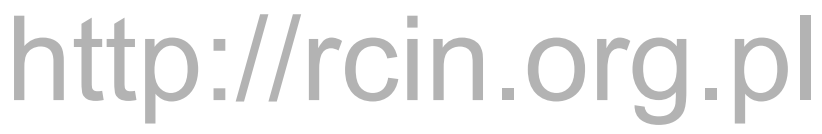


mowych warto wymienić kolejny - obserwatora wypadków wojennych, Jana Gnińskiego ${ }^{43}$. Odsiecz wiedeńska 1683 roku niewątpliwie wyzwoliła wśród wojskowych, i nie tylko, chęć spisania sukcesów wojennych króla i jego podkomendnych. Posiadamy zatem diariusze dwóch towarzyszy jazdy - Wojciecha Jana Kunaszowskiego ${ }^{44}$ oraz Mikołaja Dyakowskiego ${ }^{45}$, trzeci jest zapewne także towarzysza Jana Polanowskiego ${ }^{46}$, dwóch rotmistrzów - Kazimierza Sapiehy ${ }^{47}$ i Jana Dobrogosta Krasińskiego ${ }^{48}$ oraz generała artylerii koronnej, Marcina Kątskiego ${ }^{49}$, nie wspominając już o ogromnej liczbie anonimowych relacji i diariuszy, opisujących bitwy pod Bisambergiem, pod Wiedniem i Parkanami ${ }^{50}$. Podobnie rzecz się ma z diariuszami dotyczącymi kampanii królewskiej w 1684 roku, znalazła się jednak tutaj i jedna autorska, biskupa Stanisława Wojeńskiego ${ }^{51}$, a więc obserwatora zdarzeń. Takim samym obserwatorem był bez wątpienia królewski syn, Jakub Sobieski, uczestnik wypraw wojennych swego koronowanego ojca w latach $1683-1687^{52}$. Z tych lat, zwłaszcza z 1686 roku, zachowały się nadto anonimowe diariusze, sięgające wypadków na Podolu, Prawobrzeżu i w Mołdawii aż po rok $1690^{53}$. Rzecz ciekawa, iż prócz kilku podobnych relacji oraz tyluż poematów, nie zachowały się diariusze $z$ ostatniej wyprawy Jana III do Mołdawii w 1691 roku $^{54}$. Spod pióra komendanta twierdzy w Soroce, pułkownika Krzysztofa Rappe, wyszedł natomiast bardzo interesujący opis oblężenia jego garnizonu przez wojska tureckie, tatarskie i kozackie w 1692 roku $^{55}$. Z kolei zwycięskie działania hetmana Stanisława Jabłonowskiego przeciw Tatarom w roku 1694 (bitwa pod Uścieczkiem) przyniosły kilka anonimowych diariuszy ${ }^{56}$, także z otoczenia tegoż dygnitarza wyszły relacje opisujące $z$ kolei niezbyt pomyślne walki w obronie Lwowa w 1695 roku $^{57}$.

${ }^{43}$ Zob. J. Gniński, Relacja traktatów żórawińskich, 1676, rps BN, BOZ 1808.

${ }^{44}$ Zob. Z rękopismu Wojciecha na Kunaszowie, Nieźwiskach, Herasymowie i Euce Kunaszouskiego, skarbnika braclauskiego, rotmistrza chorqgwi..., „Czasopism Naukowy Księgozbioru Publicznego imienia Ossolińskich”, R. 3, 1830 , z. 1.

is Zob. Dyaryjusz wideńskiej okazyi Imci Pana Mikolaja na Dyakowcach Dyakowskiego podstolego latyczewskiego, wyd. J. A. Kosiński, J. Długosz, Warszawa 1983.

${ }^{46}$ Zob. Dyaryusz zemknionego woyska i partyi... w roku 1683, rps BOss. 12806; druk: Diariusz marszu wiedeńskiego..., w: K. W. Wójcicki, Biblioteka Starożytna Pisarzy Polskich, t. 5, Warszawa 1854, s. 223-238.

${ }^{47}$ Zob. K. J. Sapieha, Diariusz kampanii wegierskiej in anno 1683, wyd. O. Laskowski, „Przegląd Historyczno-Wojskowy", t. 6, 1933, z. 1.

${ }^{48}$ Zob. J. D. Krasiński, Relatia seu descriptia wojny pod Wiedniem... roku 1683, wyd. O. Laskowski, ibidem, t. 2, 1930, z. 1 .

49 Zob. M. Kątski, Diarium Artilieriae Praefecti, w: Akta do dziejów Króla Jana III sprauy roku 1683 a osobliwie uyprauy wiedeńskiej wyjaśniajace, wyd. F. Kluczycki, Kraków 1883.

so Zob. K. Zawadzki, op. cit., nr 960-1089.

${ }^{51}$ Zob. S. Wojeński, Compendiosa, sierpień 1684, rps BCzart. 10436 II.

52 Zob. diariusze królewicza Jakuba Sobieskiego z lat 1683-1687, rpsy BCzart. 1378, BN 3075 i 3094.

${ }^{53}$ Zob. K. Zawadzki, op. cit., nr 1143-1173.

${ }^{4}$ Zob. M. Komaszyński, Anonimowy poemat o ostatniej kampanii Jana III, „Śląski Kwartalnik Historyczny Sobótka”, t. 37, 1982, nr 3-4, s. 375-383.

${ }_{55}$ Zob. Dziennik oblçżenia od 27 września do 9 października 1692 posłany Sobicskiemu przez pułkownika Rappa komendanta w Soroce, rps BOss. 3003 (Teki Lukasa, nr 31).

${ }^{56}$ Zob. K. Zawadzki, op. cit., nr 1180-1184.

${ }^{57}$ Zob. W. Majewski, Najazd Tatarów w lutym 1695 r., „Studia i Materiały do Historii Wojskowości”, t. 9, 1963, cz. 1 (omówienic relacji).

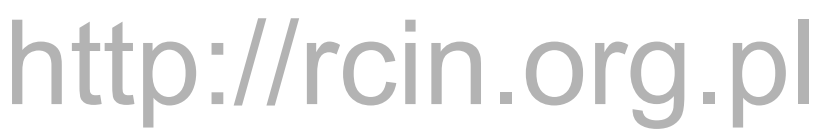


Przeważnie, ale nie wyłącznie wydarzeń lat dziewięćdziesiątych dotyczyły notatki umieszczone we wspomnianych $\mathrm{w}$ referacie pamiętnikach listowych, a więc cotygodniowych relacjach przesyłanych określonym dygnitarzom przez ich rezydentów lub po prostu agentów. Bez wątpienia, na pierwszym miejscu wymienimy lwowskiego mieszczanina, Dominika Stanisława Wilczka, który w latach 1693-1695 przesyłał cotygodniowe listy, informujące Jana III o sytuacji militarnej na pograniczu ${ }^{58}$. Znany „pamiętnikarz” Kazimierz Sarnecki, rezydent na dworze królewskim, zausznik litewskiego dygnitarza, Karola Stanisława Radziwiłła, przesyłał swemu mocodawcy regularne doniesienia polityczne i wojskowe za lata $1690-1696^{59}$. Odkryty przez autora bogaty zbiór listów jezuity i kapelana nadwornego syna hetmana, Jana Stanisława Jabłonowskiego, Tomasza Perkowicza, adresowanych do Anny Zamoyskiej, wdowy po podskarbim koronnym Marcinie, przynosi nam wiele opisów nieznanych dotychczas wydarzeń politycznych i wojskowych $z$ lat $1690-1697^{60}$. Jeżeli dwaj pierwsi informatorzy raczej obserwowali przebieg działań wojennych, to relacje owego jezuity, usadowionego blisko kwatery hetmańskiej, stanowią niezwykle ważny oraz cenny materiał dla poznania mechanizmów „pracy dowódczej” hetmana Jabłonowskiego.

W podsumowaniu nie możemy zatem pominąć obserwatorów, autorów pamiętników listowych z końcowego okresu panowania Jana III Sobieskiego. Musimy natomiast wykluczyć z naszych rozważań sporą liczbę diariuszy anonimowych (ponad 200), niewątpliwie ciekawych, ale czekających dopiero na swego historyka. Grupa analizowanych form pamiętnikarskich obejmuje łącznie 276 pozycji, w tym 21 pamiętników właściwych i 4 listowe oraz 251 diariuszy (relacji). O tym pierwszym gatunku pisaliśmy już wcześniej, warto natomiast dokonać analizy owych diariuszy — otóż okazuje się, że wydarzeń pierwszej wojny tureckiej (1672-1676) dotyczy jedynie około 15\% przekazów, zaś kolejnych zmagań z Turkami i Tatarami (1683-1696) oczywiście 85\%, jednak gdy wyodrębnimy sam rok 1683 (ponad 150 relacji), to okaże się, że wydarzenia wiktorii wiedeńskiej zawładnęły w zasadniczy sposób umysłami i motywacjami autorów, zarówno wojskowych, jak i cywilnych.

Grupa naszych pamiętnikarzy jest dobrze znana w polskiej literaturze, warto wymienić klasyczne wydania pamiętników: Jana Chryzostoma Paska, Mikołaja Jemiołowskiego, Krzysztofa Zawiszy, Jana Władysława Poczobuta Odlanickiego, także Aleksandra Dionizego Skorobohatego oraz Floriana Tuszyńskiego. Wydano drukiem krótki pamiętniczek Mikołaja Złotnickiego, w przygotowaniu są także pamiętniki Stanisława Z. Druszkiewicza. Niegdyś wydano pamiętniki Jana Stanisława Jabłonowskiego oraz Jana Antoniego Chrapowickiego, również dwóch Francuzów Filipa Duponta i Franciszka Daleraca, ale nadal oczekują na wydanie pozostałe, w tym bardzo ciekawe - Andrzeja Jana Sierakowskiego, Wodzickich, Polanowskich oraz „diariusze żołnierskie”.

\footnotetext{
${ }^{58}$ Zob. A. Sajkowski, W stronę Wiednia. Dole i niedole wojenne w świetle listów i pamiętników, Poznań 1984, s. 313-325; M. Wagner, Korespondencja Stanisław' Jabtonowskiego w systemie informacji i propagandy w końcu XVII wieku, „Podlaski Kwartalnik Humanistyczny", nr 1-2 (2-3), Sicdlce 2000, s. 203-222.

${ }^{59}$ Prócz wydanych przez J. Wolińskicgo (por. przyp. 12) zob. także relacje rękopiśmicnne - AGAD, AR, dz. V, t. 342, nr 13939, rps BN 3349.

6) Zob. M. Wagner, Stanistaw Jabtonowski..., op. cit., passim (zwł. cz. 2).
}

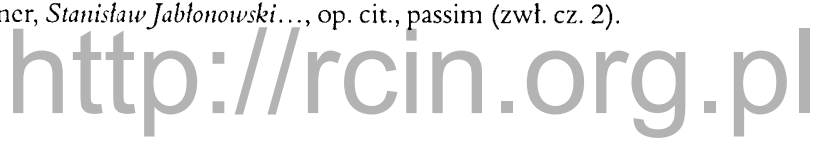


Wśród ich autorów byli reprezentanci grupy dygnitarzy koronnych, wojewodów, kasztelanów i urzędników (Druszkiewicz, Złotnicki, Opaliński, Sierakowski, Jabłonowski), również litewskich (Chrapowicki, Zawisza, Radziwiłł). Reszta reprezentowała średnie warstwy szlacheckie, szlachty raczej koronnej niż litewskiej. Bywali urzędnikami ziemskimi i magnackimi klientami, lecz przede wszystkim wojskowymi. Widzimy wśród nich towarzyszy jazdy (Skorobohaty, Odlanicki, Wodzicki, Polanowski, Jemiołowski, Tuszyński, Pasek, Kostrowski, Szyrma oraz Puchalski), rotmistrzów jazdy (Sierakowski, Opaliński, Zawisza, Jabłonowski i Radziwiłł), także pułkowników i regimentarży (Druszkiewicz, Zlotnicki), mniej zaś oficerów zaciagu cudzoziemskiego tylko dwóch owych Francuzów, inżynierów wojskowych. Widoczna zatem przewaga towarzyszy jazdy, wywodzących się ze średniej szlachty, przekładała się niejako na udowodnione w literaturze przedmiotu motywacje spisywania pamiętników, zwłaszcza po roku 1648 i 1683. Z przykrością musimy jednak stwierdzić, iż wśród autorów diariuszy (relacji) przeważali obserwatorzy wydarzeń (Paweł i Hieronim Pinocci, zapewne też Cosimo Brunetti, Józef Zimorowic, Adam Przyborowski, Stanisław Wojeński, królewicz Jakub Sobieski). Byli jednak też towarzysze jazdy (Wojciech Kunaszowski, Mikołaj Dyakowski), rotmistrzowie (Jan Dobrogost Krasiński, Kazimierz Sapieha), dwaj wspomniani oficerowie zaciągu cudzoziemskiego (pułkownik Krzysztof Rappe oraz generał Marcin Kątski), wreszcie hetmani — koronny Dymitr Wiśniowiecki i litewski Michał Pac. Jednak z powodu dużej liczby anonimowych relacji trudno dokonać nam takiej analizy, jak w przypadku autorów pamiętników. Wydaje się także, że w sporządzaniu owych diariuszy więcej tutaj motywacji niejako „urzędowych” niż osobistych, widocznych głównie w opisie wydarzeń wojennych lat 1673 i 1683, a nawet lat 1684 i 1686. Jeżeli do tego roku, jak sądzimy, ośrodkiem „motywujacym" był dwór króla Jana III Sobieskiego, to od końca lat osiemdziesiątych, a może od dziewięćdziesiątych, staje się nim kwatera hetmańska Jabłonowskiego. To znamienna zmiana, posiadająca też ważne uwarunkowania w sytuacji wewnętrznej szlacheckiej Rzeczypospolitej.

\section{Ludzie i wydarzenia}

\section{„Wojna i pokój”}

Wojna była niewątpliwie, ale i szczególnie, obecna w narracji omówionych wyżej pamiętników i diariuszy. Była bowiem sposobem na życie dla sporej przecież części naszych pamiętnikarzy, głównie dla tych, którzy zawodowo trudnili się wojaczką, zaś kampanie, obozy i bitwy wyznaczały w zasadniczy sposób rytm ich żywota ${ }^{61}$. Podstawowym problemem pozostaje więc nadal określenie motywacji wyboru służby wojskowej jako możliwości znalezienia sobie, na określonym etapie, stabilizacji życiowej. Dla części pamiętnikarzy były to przede wszystkim tradycje rycerskie, rodzinne (Tuszyński), dla innych względy osobiste, konieczność uniknięcia kary (Druszkiewicz), również chęć wysłużenia sobie nagrody, chociażby wójtostwa, za poniesione trudy wojenne

${ }^{61}$ Zob. J. Maroń, Mentalnośc żolnierzy polskich u' XVII wieku - proba sondażu, w: Studia z dziejów kultury i mentahności czasóu' nou'ożytnych, red. K. Matwijowski, B. Rok, Wrocław 1993, s. 93-102.

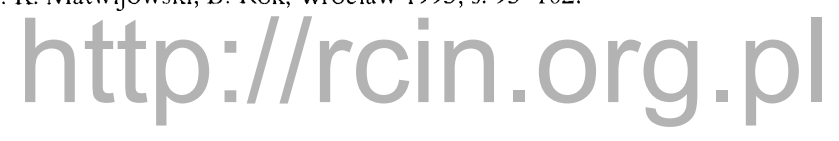


(Odlanicki). Również zakończenie służby wojskowej było czasami powodem do ogólniejszych rozważań dla pamiętnikarzy. Pułkownik Druszkiewicz nie zamierzał dalej utrzymywać własnym kosztem swych podkomendnych, ale także służyć jako rotmistrz pod innymi dowódcami. Z kolei towarzysz jazdy Tuszyński z konieczności musiał zmienić szefa oraz chorąiew, bowiem „nie nauczył [się] próżnować”. Zwycięstwa odnoszone przez wojska polskie, na przykład pod Chocimiem i pod Wiedniem, były bez wątpienia powodem do osobistego tryumfu, ale także do kontynuowania służby wojskowej (Tuszyński, Druszkiewicz).

Dla tych i innych pamiętnikarzy wojna przede wszystkim wiązała się z możliwością poniesienia śmierci w walce (Pasek, Odlanicki i Tuszyński) lub odniesienia rany w boju (Druszkiewicz, Tuszyński). Jednak prawie wszyscy odnotowywali nie tylko pojedyncze przypadki śmierci, przeważnie dygnitarzy, wyższych dowódców, a nawet szeregowych, ale także i poważniejsze straty w skali niejako masowej. Śmierć była zatem wszędzie obecna, traktowana przez pamiętnikarzy jako coś oczywistego, naturalnego, wynikającego z faktu wyboru profesji żołnierskiej.

Wojna posiadała jednak i przyjemne strony. Były to możliwości zdobycia łupów wojennych, stanowiących w jakiś sposób rekompensatę za poniesione trudy lub nagrodę za osobistą odwagę. Pisali o tych sprawach Tuszyński, Druszkiewicz i Złotnicki, ale przede wszystkim Pasek, jednoznacznie wiążąc te wydarzenia ze zmaganiami polsko-tureckimi w czasach Sobieskiego.

Na zakończenie tego akapitu należy podnieść jeszcze dwa problemy. Otóż nasi „gawędziarze”, z oczywistych powodów, zajmowali się przeważnie sprawami wojennymi, i tymi przyjemnymi, i tymi złowrogimi, pomijając prawie zupełnie okresy pokoju. Do wyjątków należą tutaj Pasek i Jemiołowski, którzy odnotowali dla lat 1677-1682 fakt ulokowania wojsk koronnych w obozach wojskowych, ochraniających ziemie polskiego pogranicza. Także jedynie ci dwaj „gawędziarze” pisali o powyższych problemach, bowiem autorzy diariuszy, skupiając uwagę na opisach działań wojennych, nie mieli chyba czasu i potrzeby glębszych przemyśleń na temat istoty „wojny i pokoju”.

\section{Żołnierze i dowódcy}

Wojskowi, w tym spora grupa naszych pamiętnikarzy, stanowili w miarę zwarte i zamknięte środowisko, wyróżniające się nie tylko przynależnością do określonej warstwy społecznej, ale przede wszystkim do zhierarchizowanej struktury zawodowej ${ }^{62}$. Wszyscy bowiem dobrze zdawali sobie sprawę, że przynależą do wyższych struktur militarnych (wojsk koronnych i litewskich), do kreślonych dywizji, pułków, chorągwi i regimentów, podlegają także dowódcom różnych szczebli. Druszkiewicz i Złotnicki, także Tuszyński, Jemiołowski, Puchalski, Skorobohaty i Odlanicki pisali o tych sprawach w sposób jednoznaczny, podkreślając swą przynależność do grona „Synów Ojczyzny”, jej wybrańców i obrońców.

Jednakże perspektywa widzenia owego środowiska była odmienna — jeśli wśród towarzyszy jazdy zamykała się ona na własnej choragwi, czasami na pułku, rzadziej na wyższej jednostce, to w grupie oficerów kolejność ta była odwrotna. Wystarczy przejrzeć chociażby zapiski Kątskiego,

${ }^{62}$ Zob. M. Wagner, Kadra oficerska armii koronnej w drugiej polowie XVII wieku, Toruń 1995, s. 188-189.

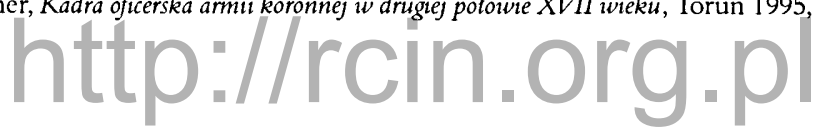


Druszkiewicza, Złotnickiego, Sierakowskiego czy Jabłonowskiego, by zorientować się, że ich „perspektywa” sięgała naczelnego dowództwa, królewskiego i hetmańskiego. Jeżeli między innymi Tuszyński i Puchalski potrafili wymienić swych bezpośrednich przełożonych (chorążego, porucznika i rotmistrza), to Sierakowski i Złotnicki, a zwłaszcza generał Kątski, obracający się w środowisku króla oraz hetmanów, doskonale znali nazwiska wyższych dowódców, rotmistrzów i pułkowników. Opinia ta dotyczy w podobnym stopniu raczej wojskowych, pamiętnikarzy tak koronnych, jak i litewskich, natomiast „obserwatorzy” gorzej radzili sobie z tymi problemami.

Jak nieoceniony Pasek wychwalał niegdyś zasługi Stefana Czarnieckiego, tak w niektórych zapiskach możemy znaleźć peany sławiące czyny bojowe Jana III Sobieskiego (Jemiołowski, Druszkiewicz, Kątski, Dupont i Dalerac), ale dotyczyły one głównie wydarzeń lat 1673 i 1683. Rzecz interesująca, iż wielu pamiętnikarzy pozostawiało na uboczu ocenę dorobku militarnego polskiego monarchy po roku 1683, to chyba oczywiste, jednak także i osoba hetmana wielkiego, Stanisława Jabłonowskiego, nie doczekała się wówczas pozytywnych opinii jako wodza armii koronnej, może z wyjątkiem notatek w pamiętnikach Złotnickiego i Sierakowskiego.

Wprawdzie kolejny problem należy raczej do zagadnień społecznych, lecz musimy także odnotować wielość poruszanych w pamiętnikach wątków tak zwanych klientarnych, i to bez względu na stopień wojskowy autorów zapisków. Jak wiemy, system „patron - klient” funkcjonował dość powszechnie w dawnej Rzeczypospolitej, a jego udziałem były w dużej mierze kręgi wojskowe, związane nie tylko ze swymi szefami, ale także z potężnymi magnatami i dworami królewskimi. Tutaj także inna była perspektywa towarzyszy jazdy (Tuszyński, Puchalski, Jemiołowski, Odlanicki), związanych z magnackimi rotmistrzami, inna natomiast wyższych dowódców (Druszkiewicz, Złotnicki, Sierakowski), raczej korzystających z patronatu króla Jana III lub hetmana Jabłonowskiego.

\section{Strategia i taktyka}

\section{Czas i przestrzén}

Europa, także Rzeczpospolita, żyła w XVII wieku w rytmie tygodniowym, powoli, lecz systematycznie, odrzucając „czas Kościoła” dla „czasu kupca lub władcy” oraz racjonalizując go na przykład w postaci rozpowszechniających się zegarów i zegarków ${ }^{63}$. Najlepiej świadczy o tym fakt, iż spośród naszych pamiętnikarzy jedynie dwóch (Tuszyński i Puchalski) używało jeszcze świąt kościelnych na określenie jednostek czasu. Pozostali konsekwentnie stosowali jednostki, powszechnie przyjęte $\mathrm{w}$ piśmiennictwie pamiętnikarskim. Były to lata oraz miesiące, czasami pory roku (Puchalski, Złotnicki, Druszkiewicz), niekiedy tygodnie, często dni i ich pory (Puchalski, Tuszyński, Druszkiewicz, Sarnecki).

${ }^{63}$ Zob. J. A. Drob, Obieg informacji $w$ Europie $w$ potowie XVII wieku $w$ świetle drukowanych i rękopiśmiennych gazet w zbiorach watykańskich, Lublin 1993, s. 245-255.

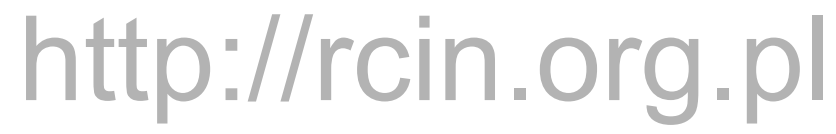


Natomiast w „diariuszach żołnierskich” autorzy stosowali powszechnie określenie wyjęte wprost ze słownictwa wojskowego, a mianowicie „ćwierć” - w znaczeniu kwartału służby wojskowej. Niejednokrotnie nasi pamiętnikarze dodawali doń przymiotnik, pochodzący od nazwy bitwy lub obozu (Tuszyński, Puchalski, Skorobohaty, Druszkiewicz, Złotnicki). W diariuszach, odnoszących się do wybranej kampanii lub bitwy, autorzy stosowali bliższe określenia czasu, jak godziny oraz kwadranse (Dyakowski, Kątski, Rappe, Sarnecki). Do wyjątków należały inne określenia - Druszkiewicz, opisując swoje potajemne przejście przez obóz tatarski, użył terminu „oświtłem” w znaczeniu zaskoczenia go przez ordyńców o świcie, a dla Puchalskiego jako określone wyróżniki czasowe ważne były daty podpisania kontraktów lub rozpoczęcia spraw sądowych. Dla omawianej formy pamiętnikarskiej charakterystyczne były przede wszystkim notatki w diariuszu Złotnickiego - rytm jego czynności wojskowych wyznaczał rozkaz hetmana o mobilizacji, potem data przybycia do obozu, przyjazd króla lub hetmana, dalej czas zwinięcia obozu i wymarszu, wreszcie marsze, potyczki i bitwy, kolejne przemarsze do obozu wojskowego i termin koła generalnego, kończącego opisywaną kampanię wojenną. Była to perspektywa dowódcy średniego szczebla, w przypadku rotmistrzów i towarzyszy jazdy wyróżniano jedynie znaczące wydarzenia militarne, głównie potyczki i bitwy z wojskami tureckimi i tatarskimi (Puchalski, Tuszyński, Skorobohaty, Dyakowski). Wydaje się, iż w odniesieniu do naszych pamiętnikarzy „czas żołnierza” odgrywał dość ważną rolę w ich zapiskach, chociaż tylko zawodowi wojskowi uczestnicy wydarzeń potrafili w sposób bardziej precyzyjny określić jego podstawowe jednostki i terminy.

Przestrzeń posiadała dla naszych pamiętnikarzy charakter ogólny oraz szczegółowy, bliższy i dalszy, w rozumieniu nie tylko wytyczenia granic poszczególnych ziem i obszarów, ale również określenia centrum i peryferii ${ }^{64}$. Zanim omówimy podstawową, nie tylko dla wojskowych, miarę odległości, a zatem milę, warto wskazać na fakt używania jeszcze terminów związanych z odległościami komunikacyjnymi, np. „wielki dzień” lub „dzień chodu na koniu dobrym” (Tuszyński). Prawie wszyscy nasi pamiętnikarze poruszali się zresztą „w promieniu” kilku mil (do 4-5), rzadziej większym - do 40 mil (Skorobohaty).

Tyle słów wstępu, problem ten wymaga bowiem bliższego wyjaśnienia, gdyż w pamiętnikach i diariuszach pojawiają się różne rodzaje mili. Wiemy, że mila staropolska liczyła $7146 \mathrm{~m}$, podolska, czyli ukraińska - $10480 \mathrm{~m}$, zaś wołoska - $5853 \mathrm{~m}$. Zdaniem Ulryka Werduma, podróżnika po Ukrainie i Podolu w latach 1670-1672, mila podolska (ukraińska) w porównaniu do mili polskiej zwiększała swoją długość na ziemiach graniczących z państwem osmańskim i z tych powodów odległości obliczano według liczby dni podróży. Musimy zawierzyć naszemu pamiętnikarzowi, potwierdzając, że stosowana przez wojskowych „mila” była milą podolską, czyli ukraińską, liczącą około $10,5 \mathrm{~km}^{65}$.

${ }^{64}$ Zob. ibidem, s. 152-206.

${ }^{65}$ Zob. U. Werdum, Tagregister von dem Feldzüge ... 1671, wyd. X. Liske, „Scriptores Rerum Polonicarum”, t. 4, Kraków 1878, s. 211-215.

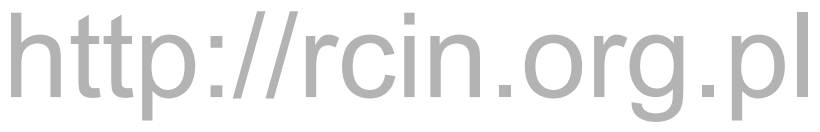


Wszyscy pamiętnikarze dobrze orientowali się w prawnie wytyczonych granicach prowincji i województw Rzeczypospolitej, znali i wymieniali nazwy miast i miasteczek, rzadziej jednak wsi lub mniejszych osad, związanych z trasami przemarszów lub miejscami obozowania. W sumie należy podkreślić bardzo dobrą orientację $\mathrm{w}$ terenie działań wojennych (Dyakowski, Puchalski, Złotnicki, Druszkiewicz). Trzeba tutaj wyróżnić szczególnie dwóch autorów (Tuszyński, Kątski), którzy nie tylko prawidłowo opisali teren, ale dokonali również jego analizy pod kątem przydatności w określonych działaniach taktycznych. Pierwszy, analizując obszary położone nad Bohem, znakomicie przedstawił możliwości przeprawy przez rzekę i opisał tereny zalesione, zaś generał artylerii koronnej analizował tereny usytuowane pod Wiedniem i pod Parkanami z punktu widzenia taktycznego. Podobne uwagi, chociaż nie tak szczegółowe, odnajdziemy także w diariuszu pułkownika Rappe, opisującego działania obronne garnizonu w Soroce, natomiast z oczywistych powodów w relacjach „obserwatorów” rozpoznawalność szczegółów terenu posiadała charakter ogólniejszy.

Dla większości naszych pamiętnikarzy „centrum” to obszary położone w sercu rozgrywających się działań wojennych - Podole, Prawobrzeże, także Moldawia, z kolei dla autorów diariuszy - Chocim, Wiedeń, Parkany i Soroka, a zatem miejsca bitew i potyczek z wojskami tureckimi i tatarskimi. Peryferie bliższe to bez wątpienia obszary usytuowane na pólnoc od granicy zaboru tureckiego, a więc rejon Lwowa i obszary położone wokół miasta. Znajdowały one swe odzwierciedlenie w diariuszach „hetmańskich” z lat siedemdziesiątych (Pac, Wiśniowiecki), a także w pamiętnikach listowych $z$ lat dziewięćdziesiątych XVII wieku (Sarnecki, Perkowicz, Wilczek). Wynikało to z powodów czysto militarnych, tutaj bowiem znajdowała się główna kwatera hetmana koronnego oraz rejon koncentracji wojsk polskich. Z kolei peryferie dalsze to niewątpliwie ziemie centralne Korony i Litwy, chociaż w niektórych pamiętnikach pojawiają się także obszary, na których ulokowane były majątki naszych wojskowych albo magnatów (Radziwiłł, Jabłonowski) lub też szlachty (Sierakowski, Puchalski, Polanowski, Kunaszowski).

\section{Strategia i taktyka}

Pamiętnikarze Sobieskiego w dość jednoznaczny sposób odnosili się do zagadnień strategicznych, związanych przede wszystkim z miejscem zajmowanym przez danego autora w hierarchii wojskowej. Miejsce to, jak piszą historycy, wyznaczało im określoną perspektywę oglądu wojny, widzianą albo oczami dowódcy, albo szeregowego żołnierza ${ }^{66}$. Rzecz jednak ciekawa, iż w znanych diariuszach hetmańskich (Pac, Wiśniowiecki) rzadko odnajdziemy analizę podstawowych zagadnień strategicznych; niektórych jedynie elementów dotykają przekazy dowódców średniego szczebla (Druszkiewicz, Zlotnicki), również francuskich inżynierów (Dupont, Tende, Dalerac), którzy dobrze orientowali się w planach strategicznych i operacyjnych polskiego dowództwa.

Fragmenty dotyczące analizy wybranych tylko zagadnień strategicznych znajdziemy w pamiętnikach towarzyszy jazdy, chociaż brak tutaj szerszych rozważań, bowiem ograniczają się jedynie do opisu określonych kampanii wojennych. O planach wojennych polskiego dowództwa w latach 1674-1675

to Zob. J. Maroń, op. cit., s. 93-94.

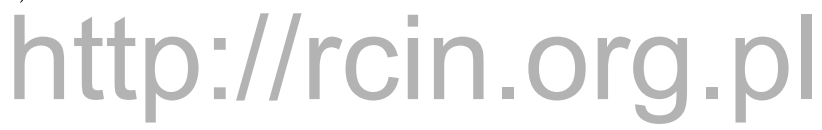


pisał, ale dość pobieżnie, Jemiołowski, a o wyprawie wiedeńskiej 1683 roku - Dyakowski, o konieczności z kolei zabezpieczenia pogranicza przed najazdami tatarskimi w latach 1675-1676 — Tuszyński i Jemiołowski. Niekiedy pojawiają się także opinie o militarnym znaczeniu twierdz, miast i warownych obozów (Pasek, Dyakowski, Skorobohaty, Tuszyński, Jemiołowski, Dupont, Dalerac), a także, lecz bardzo ogólne, uwagi na temat poszczególnych kampanii wojennych, szczególnie po roku 1683 (Pasek, Skorobohaty).

Podobnie jak w wypadku oglądu wojny z punktu widzenia strategii, tak w odniesieniu do taktyki miejsce zajmowane przez naszych pamiętnikarzy w hierarchii wojskowej wyznaczało im sposób określenia i opisania wybranych elementów sposobów walki. Pułkownik Złotnicki doskonale był zorientowany w celach działań taktycznych: obronnych i zaczepnych, podczas działan na Podolu w latach osiemdziesiątych z wojskami tureckimi i tatarskimi. Z kolei regimentarz Druszkiewicz, bez wątpienia także dość dobrze zaznajomiony z celami działań taktycznych, był bardziej powściagliwy w narracji, podobnie jak rotmistrzowie jazdy koronnej i litewskiej (Sierakowski, Jabłonowski, Zawisza). Jednakże prawie wszyscy rotmistrzowie i towarzysze jazdy podkreślali w narracji taktyczne elementy przemarszów i obozowania, wykazując się dobrą ich znajomością, widzianą przez pryzmat dowódcy albo szeregowego żołnierza. Podobnie kształtowała się sytuacja w wypadku opisów wybranych potyczek lub bitew z wojskami tureckimi lub tatarskimi. Wszyscy bowiem towarzysze jazdy doskonale byli zorientowani w liczebności i uszykowaniu wojsk polskich - wyróżniali zatem podstawowe jego elementy, jak centrum, skrzydła oraz odwody (Tuszyński, Dyakowski, Jemiołowski, Skorobohaty), zaznaczając niejednokrotnie warunki klimatyczne podczas starć zbrojnych (Kostrowski, Dyakowski). Opis i analiza taktyki walki zmieniały jednak swoją optykę w aspekcie chronologicznym. Jeżeli bowiem narratorzy opisujący wojnę lat 1672-1676 oraz kampanię wiedeńską 1683 roku zwracali szczególną uwagę na wielkie i zwycięskie dla Jana III batalie (Chocim, Lwów, Żórawno, Wiedeń), przekazując czytelnikowi w miarę dokładny obraz walk, to pamiętnikarze i autorzy diariuszy od 1684 roku nie byli tak szczegółowi w swej analizie - wyjątkiem był tutaj Złotnicki, opisujący oblężenie Kamieńca Podolskiego w 1689 roku oraz bitwę pod Uścieczkiem w 1694 roku.

Nasi pamiętnikarze nie bardzo jednak orientowali się w podstawowych elementach taktyki wojsk przeciwnika, ich wiedza była zbyt ogólnikowa, ale zdarzały się także i tutaj wyjątki naszym zdaniem opis obozu tureckiego pod Chocimiem (1673) dokonany przez Tuszyńskiego zasługuje na szczególną uwagę historyków wojskowości. Podobnie rzadko odnotowujemy w analizowanym materiale przypadki opisu i analizy techniki walki, „taktyki pojedynczego żołnierza”. Jedynie ceniony przez historyków Pasek i może Druszkiewicz, podejmowali szerzej omawianą problematykę, opisując w znakomity sposób pojedynki Polaków z Rosjanami, Turkami i Tatarami.

$\mathrm{Na}$ tym tle niewątpliwie wyróżnia się narracja generała artylerii koronnej, Marcina Kątskiego, i temu właśnie diariuszowi z bitwy wiedeńskiej 1683 roku należy poświęcić więcej uwagi. Otóż ów dowódca $z$ racji zajmowanego $w$ wojsku stanowiska był doskonale zaznajomiony nie tylko $z$ planami taktycznymi batalii (jako uczestnik narad wojennych), ale także z terenem przyszłych zmagań zbrojnych, biorąc udział w rekonesansie przed bitwą i czerpiąc informacje od ,języków”. Pomijając opis

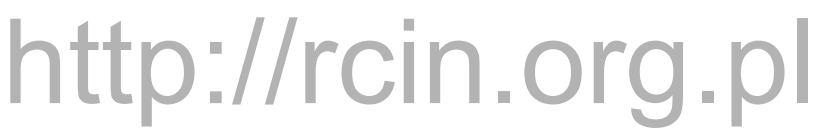


przemarszu wojsk polskich, a zwłaszcza korpusu artylerii, przez wzgórza Lasu Wiedeńskiego, musimy przede wszystkim podkreślić znakomitą orientację w uszykowaniu oddziałów sprzymierzonych podczas bitwy. Narracja generała przynosi nam zatem opis szyku, podziały na centrum, skrzydła i odwody, dodatkowo na linie, straże przednie, „fortropy”, „posiłki” i „bateryje” oraz rozróżnienie na dywizje i brygady z podaniem ich liczebności i nazwisk dowódców. Nie unikał także nasz dowódca notatek dotyczących warunków terenu lub też godzin określających poszczególne fazy batalii wiedeńskiej. W opisie i analizie jej przebiegu również widać znakomitą i fachową znajomość elementów taktyki wojsk polskich, jednostek sprzymierzonych czy też oddziałów przeciwnika. Podobne uwagi odniesiemy także do opisu bitwy pod Parkanami, tej drugiej i zwycięskiej dla Jana III, gdzie nasz pamiętnikarz sprawował komendę nad polskim korpusem artylerii.

Jeżeli zatem wyróżnimy pamiętniki nieocenionego Paska jako znakomitą gawędę historyczną, to niewątpliwie diariusz Kątskiego zasługuje na ocenę fachowego dzieła historyczno-wojskowego, spisanego przez znakomitego i doświadczonego dowódcę wojsk polskich. Jak się wydaje, diariusz generała otwiera w ówczesnej literaturze pamiętnikarskiej nowy etap piśmiennictwa naszych wojskowych, a mianowicie coraz częściej i chętniej zaczynają oni posługiwać się taką właśnie formą, określaną mianem „diariuszy żołnierskich”, bardzo zresztą popularnych na zachodzie Europy, by przywołać jedynie przykłady angielskie, o których szeroko pisał przed drugą wojną światową Arthur Ponsoby. Trudno nam jednak zgodzić się z opinią tegoż badacza, że diariusze:

jako całość są nudne. Większość z nich ma schemat: pragnienie wzięcia udziału w bitwie, niecierpliwość okresu wyczekiwania, oczekiwanie końca wojny. (...) ...nie opisze się nigdy dobrze marszów i pochodów, ruchów wojsk, posunięć taktycznych i organizacji. Rzadkie są diariusze, w których autor potrafi dać rzeczywisty obraz graficzny scen i zdarzeń ${ }^{67}$.

Tyle Ponsoby o XVII-wiecznych diariuszach angielskich. Przykłady polskie (zwłaszcza Kątski, lecz także Rappe, Złotnicki i Dyakowski, Dupont i Dalerac) moga jednak przeczyć takim opiniom, chociaż bez wątpienia pozostaje fakt, że nie tylko chęci, ale przede wszystkim zawodowa perspektywa autorów decydowały o sposobie narracji w odniesieniu do zagadnień strategicznych i taktycznych.

\section{Organizacja i dyscyplina}

Nie potrzeba chyba udowadniać znanej opinii, że najlepsze, chociaż niezbyt obiektywne oceny stanu organizacji i uzbrojenia, finansowania, logistyki i dyscypliny wojsk polskich, wyszły spod piór cudzoziemskich, między innymi francuskich pamiętnikarzy (Dupont, Dalerac, de Tende). Bez wątpienia nasi wojskowi o wiele lepiej byli zorientowani w tej skomplikowanej i zawiłej strukturze, ale też nie wszyscy uważali za konieczne szerzej pisać o tych sprawach ${ }^{68}$. Także i tutaj inna była perspektywa dowódcy, a inna szeregowego - Druszkiewicz i Złotnicki obracali się w kręgach

${ }^{67}$ Cyt. za: A. Cieński, op. cit., s. 133.

${ }^{68}$ Zob. Z. Libiszowska, Wojsko polskie w XVII wieku w śuietle relacji cudzoziemskich, „Studia i Materiały do Historii Wojskowości”, t. 5, 1960, s. 244-267.

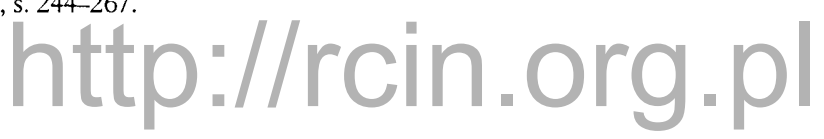


wojskowych na szczeblu partii, dywizji i pułków, a towarzysze jazdy jedynie w swych chorągwiach. To oni właśnie (Pasek, Tuszyński, Puchalski i Skorobohaty) przekazali nam obraz tworzenia i organizacji chorągwi, a także codziennego życia towarzyszy broni. Odnajdziemy tutaj zatem nazwiska żołnierzy, jak również i ich dowódców, stan wyszkolenia i dyscypliny, a nawet ceny koni czy też uzbrojenia (Skorobohaty).

Nie można oczywiście pominąć tutaj znakomitej gawędy Paska, który w sugestywny sposób przekazał nam swoją opinię o „przydatności” pospolitego ruszenia w walkach z Turkami i Tatarami w 1672 roku, czy też Tuszyńskiego, ten z kolei opisał reorganizację chorągwi pancernej na husarską („usarzyć się”) lub formy karania przez dowódcę niesfornych podkomendnych (akapit o krzesaniu ognia „do tutoniu” na bandoletach).

\section{Wrogowie i przeciwnicy}

Obraz, ogólnie mówiąc, stanu i oceny wojskowości przeciwników nie zajmował wiele uwagi pamiętnikarzy Jana III Sobieskiego ${ }^{69}$. Były to bowiem ogólnikowe opinie na temat wojsk tureckich i tatarskich, rzadziej Mołdawian, niewskazujące na potrzebę zajmowania się szerzej tymi problemami. Nie sposób jednak pominąć dobrych opinii Daleraca i Duponta, a więc cudzoziemców, o ogólnym stanie wojskowości tureckiej lub tatarskiej oraz o sytuacji na Podolu i Prawobrzeżu pod okupacją turecką. Do rzadkości jednak należą krótkie opisy zwyczajów dowódców i wojsk tureckich (Jemiołowski, Tuszyński) lub też sposobów walki czambułów tatarskich, które posuwały się ,jak piłką rzucił” (Pasek, Tuszyński).

Odmiennie kształtował się obraz naszych „wrogów” - Turcji, chanatu krymskiego i hospodarstw naddunajskich — w relacjach pamiętnikarzy w porównaniu choćby do rozpowszechnionych wówczas w Polsce i w Europie ,gazet pisanych". Historycy polscy już udowodnili, że szczególnie obraz państwa i wojsk osmańskich, z oczywistych powodów, zajmował w owych przekazach wiele miejsca, natomiast, jak się wydaje, nasi wojskowi pamiętnikarze nie widzieli ani potrzeby, ani konieczności opisywania omawianych zagadnien ${ }^{70}$. Naszym zdaniem, także ich miejsce w hierarchii wojskowej nie wystarczało do formułowania szczególowych ocen (z wyjątkiem Kątskiego, Druszkiewicza i Złotnickiego) na temat zdolności bojowych wojsk tureckich lub tatarskich. Te bowiem wiadomości czerpano przede wszystkim z relacji agentów wywiadu wojskowego, dostępnych jedynie królowi, hetmanom i wyższym dowódcom wojsk polskich.

\section{Opinie i wnioski}

Wielu badaczy przed autorem niniejszego artykułu, podejmowało i z pewnością podejmować będzie w przyszłości badania nad staropolskimi pamiętnikami, starając się dokonać ich rzetelnej oceny. Zadanie to jest niezwykle trudne, nie tylko z powodu potwierdzonego faktu funkcjono-

\footnotetext{
69 Zob. ibidem, s. 256.

70 Zob. K. Maliszewski, Obraz śmiata i Rzeczypospolitej u' polskich guazetach rękopiśmiennych zokresu późnego baroku, Toruń 1990, s. $111-119$

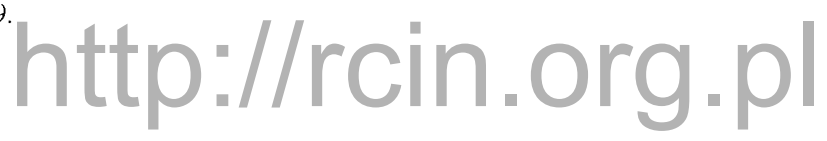


wania różnych form pamiętnikarskich, ale także z prostej przyczyny - wiele pamiętników i diariuszy spoczywa w niezbadanych jeszcze zespołach archiwalnych. Mimo tych trudności, pokusimy się przynajmniej o próbę sformułowania końcowych wniosków.

Pamiętniki i diariusze niewątpliwie przynależą do opisanego w literaturze przedmiotu ,wieku rękopisów”, czyli do XVII wieku, a w przypadku naszego wystąpienia do „późnego baroku”, sięgającego od lat siedemdziesiątych XVII wieku po lata trzydzieste następnego stulecia. Cezurą chronologiczną może być tu „haniebny rok 1672”, rok upadku Kamieńca Podolskiego i dwóch konfederacji - gołąbskiej i szczebrzeszyńskiej. Zgadzamy się więc z opinią znakomitego znawcy barokowej literatury, Janusza Pelca, iż po tym roku w mentalności polskiej szlachty zachodzą zmiany, charakteryzujące się zniechęceniem oraz marazmem, także pesymistycznym widzeniem rzeczywistości. I tylko zwycięstwa pod Chocimiem i Wiedniem na krótko przerywają lata letargu — stan taki trwa aż po rok śmierci wielkiego monarchy, Jana III, i bez wątpienia dalej w następnym stuleciu ${ }^{71}$.

Lata „upadku i chwały”, a więc między 1672 a 1683 rokiem, posiadają także swoje odzwierciedlenie w pamiętnikarstwie wojskowym - tutaj bowiem odnajdziemy jeszcze cenione pamiętniki, natomiast po roku 1684 pojawiają się coraz liczniejsze diariusze i relacje wojskowe, bardziej może fachowe, tym bardziej zajmujące uwagę historyków wojskowości. Nie możemy zatem zgodzić się z opinią badacza i wydawcy, Bohdana Królikowskiego, że w czasach Jana III ówczesne pamiętniki obniżają swoją wartość ${ }^{72}$. Częściowa to tylko prawda, bowiem ich miejsce zajmują właśnie analizowane diariusze, i te „żołnierskie”, i te „cywilne”. Nadal posiadają one charakter użytkowy, o znacznym stopniu subiektywizmu w widzeniu i opisie wydarzeń wojennych, gdyż przeważnie były sporządzane po wielu latach na podstawie wcześniej dokonanych notatek. Uwagi te odnoszą się zwłaszcza do szczególnych form osobistych zapisków, na przykład „diariuszy oblężeń" (Rappe, Zimorowic) oraz relacji dotyczących określonych starć zbrojnych (Kątski) ${ }^{73}$.

Na zakończenie pozwolimy sobie jeszcze na postawienie pytania, które od dawna nurtowało autora i na które nadal próbuje znaleźć odpowiedź: dlaczego Jan III Sobieski nie spisał pamiętników, a gdyby tak się stało, jakie by one byly - czy takie jak znanego gawędziarza Paska, czy jak generała Kątskiego? ${ }^{74}$

\footnotetext{
${ }^{71}$ Zob. J. Pclc, Barok - epoka przeciuienistu', Warszawa 1993, s. 30-31, 73-83 i 295; takżc C. Hernas, Literatura baroku, Warszawa 1989, s. 170 i n.

72 Zob. B. Królikowski, Pamiętnikarstuo polskie w „uieku pamiętników”, „Pamiçtnikarstwo Polskic”, t. 7, 1977, nr 1-4, s. 90.

${ }^{73} \mathrm{Na}$ potrzebę spisywania diariuszy wojennych wskazuje często ówczesna korespondencja szlachty i dygnitarzy, zob. F. Potocki do prymasa J. S. Wydżgi, Lwów 28 XII 1684, rps BN, BOZ 933, k. 129v-130; M. Szołdrski do J. Korzbok Łąckicgo, b.m. [luty] 1685, rps BUW 71, s. 270-273.

${ }^{74}$ Postawione $\mathrm{w}$ ten sposób zagadnienic spotkało się podezas obrad konferencji z żywym odzewem ze strony dyskutantów, sugerujących pozostawienic przez Jana Sobieskicgo, zamiast formalnego, „pamiçtnika listowego” w postaci bogatego zbioru listów do swej żony, Marii Kazimicry. Zdaniem referenta, opinia taka jest nicwątpliwie trafna, jednakżc pozostawia na uboczu prac badawczych liczne kręgi korespondencyjne hetmana oraz króla, miçdzy innymi wymianç listów z dostojnikami koronnymi i litewskimi, przechowywanych obecnic w zbiorach krajowych i zagranicznych (by wymienić tylko archiwa w Mińsku lub w Berlinic). Wydaje się, że przedstawiony wyżcj problem czeka nadal na swego historyka, w postaci monografii takicj jak na przykład Wojciccha Jurkicwicza, Korespondencja elit Polski stanistawowskiej. Analiza u'ybranych kreggów korespondencyjnych, Bydgoszcz 1992.
}

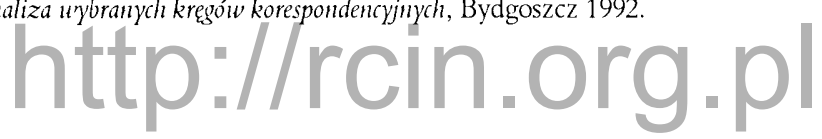

